\title{
MANAJEMEN PELAYANAN ISLAMI DALAM MENINGKATKAN KEPUASAN KONSUMEN DI TOKO ALFA BAROKAH KECAMATAN GAYAM KABUPATEN SUMENEP
}

\author{
Santi Ekawati, A. Muhyiddin Khotib \\ ekawatisantika97@gmail.com, muhyiddin.mu67@gmail.com
}

\begin{abstract}
ABSTRAK
The creation of consumer or customer satisfaction can make a harmonious relationship between service providers and customers. Since the establishment of the Alfa Barokah store, the needs of the community on the island of Sapudi have begun to be easy and easy to shop in meeting their daily needs. Provide and serve all the needs of the community in order to obtain financial and strengthen business management that is oriented towards service and obtaining halal profits, providing good customer service, providing all products for consumer needs. The discussion in this study is as follows: How is Islamic Management in increasing customer satisfaction at the Alfa Barokah store, Gayam District, Sumenep Regency? And what are the inhibiting and supporting factors in increasing customer satisfaction at the Alfa Barokah store, Gayam District, Sumenep Regency? Based on the results of research and studies that have been carried out by researchers, it shows that 1) Alfa Barokah Stores have treated consumers Islamically such as applying smiles, greetings and greetings to customers, paying attention to appearance and keeping clothes neat, having good and polite employees, providing some facilities and infrastructure and also respects customers like a king. 2) The inhibiting factor for the Alfa Barokah store is the slow delivery of goods due to weather factors. While the supporting factor is applying the attitude of Compliance, Reability, Empathy to customers.
\end{abstract}

Keyword: Manajemen, Pelayanan dan Kepuasan Konsumen

\section{PENDAHULUAN}

Berkembangnya sistem ekonomi dan bisnis Islam adalah sala satu indikasi bahwa Islam nyata adalah agama yang sempurna di muka bumi. Karena Islam mengatur (manage) 
hal-hal kecil dalam kehidupan manusia sampai kepada hal-hal yang besar, mengatur kehidupan masa kini (dunia) dan kehidupan masa depan (akhirat). Pengaturan Islam tentang kehidupan masa menjadi terarah, teratur, seimbang, dan menjadikan hidup manusia menjadi berkualitas (Rivai Veithzal, dkk, 2017).

Begitu juga dalam masalah hukum syari’at yang mengatur kehidupan manusia, mulai syari'at dalam beribadah, hubungan antar sesama manusia, sampai hukum syari'ah bermuamalah. Bukan hanya hukum ekonomi tetapi etika dalam bisnis pun sudah di atur secara lengkap. Rasulullah SAW. Merupakan tauladan yang baik untuk ummat manusia beliau sangat memperhatikan nilai moral dalam berbisnis.

Rasulullah SAW. Adalah pelopor bisnis yang berdasarkan prinsip kejujuran, transaksi bisnis yang adil dan sehat. Beliau juga tidak segan mensosialisasikan prinsipprinsip bisnisnya dalam bentuk edukasinya dan pelayanan yang tegas kepada para pembisnis yang lainnya (Rivai Veithzal, dkk, 2017). Tujuan utama berdirinya setiap usaha adalah memberikan nilai dan kepuasan kepada para konsumen melalui penyampaian produk dan jasa yang berkualitas dengan memperhatikan kebutuhan dan keinginan konsumen .

Dalam bisnis hal apapun tidak bisa melepaskan diri dari kualitas pelayanan. Apa lagi dalam bisnis jasa, pelayanan yang berkualitas menjadi hal yang sangat penting sebagai pemberian mutu tertinggi kepada konsumen. Konsumen akan merasa puas jika sistem pelayanan yang diberikan sesuai dengan apa yang diharapkan konsumen. Sebaliknya konsumen akan merasa kecewa jika system pelayananan yang diberikan tidak sesuai dengan yang di harapkan pelanggan.

Salah satu tindakan yang di lakukan untuk meningkatkan kepuasan konsumen adalah dengan cara memberikan pelayanan yang prima kepada konsumen. Pelayanan prima (excellen service) adalah pelayanan sebaik-baiknya kepada pelanggan sehingga menimbulkan rasa puas para pelanggan (Rusdiana, 2014 ). Karena nilai dan kepuasan pelanggan merupakan kunci untuk mengembangkan dan menata hubungan pelanggan (Philip Kotler, 2008) .

penerapan falsafah penjual perlu adanya suatu upaya pelayanan dari pihak penjual yang dapat menimbulkan rasa puas bagi pembeli. Dalam melakukan penjualan produk 
perusahaan penjual perlu memperhatikan pelayanan kepada pembeli dengan serius, baik pelayanan sebelum menjual maupun setelah menjual. Jika hal tersebut di lakukan penjual dengan baik, maka pembeli akan merasa puas karena telah melakukan penjualan dengan baik. Disamping penjual hharus berfikir bahwa costumer is the king (pembeli adalah Raja ) karena jika pribahasa tersebut diterapkan dengan tepat, penjual akan memiliki langganan yang banyak (A.A.Anwar Mangkunegara, 2012).

Toko Alfa Barokah yang terletak di pulau Sapudi Kecamatan Gayam Kabupaten Sumenep merupakan toko yang sangat di minati oleh konsumen atau pelanggan karena memiliki nilai jual yang tinggi. Toko tersebut awalnya merupakan toko kecil yang berada di dalam pasar yang kemudian pindah ke luar pasar tepatnya di pinggir jalan raya menjadi toko yang besar dan luas. Toko Alfa Barokah didirikan pada tahun 2004 yang kemudian direnovasi tahun 2015 sampai sekarang.

Toko Alfa Barokah menjual kebutuhan konsumen seperti baju, alat elektronik seperti kipas angin dan peralatan dapur,serta alat kebutuhan sekolah dan juga menjual sembako dan juga kitab. Toko Alfa Barokah juga dilengkapi dengan sarana dan prasarana berupa kapasitas tempat yang nyaman, luas, bersih, serta menyediakan tempat parkir yang luas serta gratis untuk para pelanggan yang berbelanja di toko Alfa Barokah.

Kasus yang terjadi di lapangan adalah kualitas yang di tawarkan oleh toko Alfa Barokah serta pelayanan yang baik dari pihak toko Alfa Barokah merupakan hal yang dapat meningkatkan kepuasan konsumen. Kepuasan konsumen memberikan informasi mengenai kualitas pelayanan kepada orang lain sehingga menciptakan banyak pelanggan.

Toko Alfa Barokah menciptakan loyalitas terhadap pelanggan sehingga bisa menarik konsumen berbelanja di toko Alfa Barokah. Toko Alfa Barokah mengedepankan sistem pelayanan yang baik, salah satunya adalah karyawan harus bersikap baik, seperti karyawan harus bersikap santun dan ramah serta selalu menerapkan senyum dan tidak memasang muka yang masam serta acuh tak acuh dan bersikap lemah lembut terhadap pelanggan.

Oleh karena itu, peneliti tertarik untuk melakukan kajian dengan fokus permasalahan: Bagaimana Manajemen Pelayanan Islami dalam Meningkatkan Kepuasan Konsumen di Toko Alfa Barokah Kecamatan Gayam Kabupaten Sumenep? dan Apa saja 
Faktor Penghambat dan Pendukung dalam meningkatkan Kepuasan Konsumen di toko Alfa Barokah Kecamatan Gayam Kabupaten Sumenep?

\section{KAJIAN TEORI}

\section{Pengertian Manajemen}

Manajemen adalah memperoleh hasil melalui berbagai kegiatan yang dilakukan orang lain.menurut Jhon D Millet, Manajemen ialah suatu proses pengarahan dan pemberian fasilitas kerja kepada orang-orang yang telah di organisasi dalam kelompokkelompok formal yang mencapai tujuan dan harapan (Rivai Veithzal, dkk, 2017).

Manajemen Islami merupakan seni memperoleh hasil melalui berbagai kegiatan yang dilakukan oleh orang lain (Rivai Veithzal, dkk, 2017). Manajemen merupakan kebutuhan penting untuk memudahkan pencapaian tujuan manusia dalam organisasi. Manajemen diperlukan untuk mengelola berbagai sumber daya organisasi, seperti waktu, sarana dan prasarana, SDM, metode, waktu dan sebagainya. Manajmen juga menunjukkan cara-cara yang lebih efektif dan efisien dalam pelaksanaan suatu pekerjaan. Dengan manajemen telah memungkinkan untuk mengurangi hambatan-hambatan dalam rangka pencapaian suatu tujuan (Rivai Veithzal, dkk, 2017).

\section{Kategori Manajemen Islami}

Dalam rumusan Abu Sin, ada empat hal yang harus terpenuhi untuk dapat di kategorikan manajemen Islami: Pertama, Manajemen Islami didasari nilai-nilai dan akhlak Islami. Etika bisnis yang ditawarkan oleh Islam berlaku universal tanpa menegenal ras dan agama. Boleh saja berbisnis dengan label Islam dengan segala atributnya, namun bila nilainilai dan akhlak berbisnis ditinggalkan, cepat atau lambat bisnisnya akan hancur. Kedua, kompensasi ekonomis dan penekanan terpenuhinya kebutuhan dasar pekerja. Cukuplah menjadi kezaliman bila perusahaan memanipulasi semangat jihad seorang pekerja dengan menahan haknya, kemudian menghiburnya dengan pahala yang besar. Urusan pahala Allah yang mengatur, urusan kompensasi ekonomis, kewajiban perusahaan membayarnya. Ketiga, faktor kemanusiaan dan spiritual sama pentingnya dengan kompensasi ekonomis. Pekerja diperlukan dengan hormat dan diikutsertakan dalam pengambilan keputusan. Tingkat partisipatif pekerja tergantung pada intelektual dan kematangan psikologinya. Bila hak-hak ekonomisnya tidak ditahan, pekerja dengan semangat jihad akan mau dan mampu 
melaksanakan tugasnya jauh melebihi kewajibannya. Keempat, sistem dan struktur organisasi sama pentingnya. Kedekatan atasan dan bawahan dalam ukhuwah Islamiyah, tidak berarti menghilangkan otoritas formal dan ketaatan pada atasan selama tidak bersangkut dosa (Rivai Veithzal, dkk, 2017).

\section{Ciri Manajemen Islami}

Ciri manajemen Islami adalah amanah, dimana jabatan merupakan amanah yang harus dipertanggung jawabkan kepada Allah. Seorang manjer harus memberikan hak-hak orang lain, baik mitra bisnisnya ataupun karyawannya. Pimpinan harus memberikan hak untuk beristirahat dan hak berkumpul dengan keluarganya kepada bawahannya. Ini merupakan nilai-nilai yang diajarkan manajemen Islam. Amanah yang telah dibebankan kepada seoraang manajer harus benar-benar dijaga. Karena seorang manajer mempunyai tanggung jawab yang besar dan untuk kepentingan banyak orang. Jika dia tidak amanah, maka akan menimbulkan bencana besar bagi sebuah bisnis.

Ciri manjemen Islami yang membedakan dengan manajemen ala Barat adalah seorang pimpinan dalam manajemen Islami harus bersikap lembut terhadap bawahannya. Contoh kecil seorang manajer yang menerapakan kelembutan dalam hubungan kerja adalah selalu memberikan senyum ketika berpapasan dengan karyawan dan mengucapkan terima kasih ketika pekerjaannya sudah selesai. Bukankan memeberikan senyum salah ibadah dalam Islam. Namun kelembutan tersebut tak lantas menghilangkan ketegasan dan disiplin. Jika karyawan tersebut melakukan kesalahan, tegakkan aturan. Pertegakan aturan harus konsisten dan tak pilih kasih.

Untuk aspek keadilannya, Islam menegakkan pentingnya riward control dalam suatu hubungan kerja. Seorang karyawan yang berprestasi tinggi mendapat penghargaan khusus. Bentuk penghargaan bukan hanya berupa materi, tapi juga berupa perhatian. Berikut ini merupakan ciri manajer manajer yang Ri'ayah (berjiwa pemimpin) : Berikan perhatian atau kepedulian kepada bawahan,buat perencanaan kerja yang baik, bersungguh-sungguh dan teliti dalam melaksanakan rencana kerja, lakukanlah pengawasan secara terus menerus, lakukan evaluasi hasil secara berkala, tegakkan disiplin dalam waktu kerja dan memikul tanggu jawab terhadap hasil akhir. 


\section{Pelayanan Islami}

Pelayanan menurut kamus besar bahasa Indonesia dinyatakan pelayanan adalah perihal dan memudahkan yang diberikan sehubungan dengan jual beli barang dan jasa (WJS Poerwa Darminta, 1976). sedangkan definisi pelayanan secara rinci adalah suatu aktifitas atau serangkaian aktivitas yang bersifat tidak kasat mata (tidak dapat diraba) yang terjadi sebagai akibat adanya interaksi antar konsumen dengan karyawan atau hal-hal lain yang disediakan oleh perusahaan pemberi pelayanan yang dimaksudkan untuk memecahkan suatu pemasalahan konsumen atau pelanggan (Ratminto, Atik septiwinarsih, 2007).

Dalam sebuah usaha di perlukan adanya pengelolaan tempat-tempat yang pembelanjaan untuk mempertahankan para konsumennya dengan terus menungkatkan mutu layanan. Karena konsumen merupakan aset terpenting dan yang menentukan maju mundurnya sutau perusahaan. Salah satu indikator yang dapat digunakan untuk mengukur kepuasan konsumen adalah kualitas layanan (Dewi Maharani purbasari, Dewi Laili Purnama Sari, 2018).

Dengan adanya pelayanan yang baik terhadap konsumen akan membuat konsumen dapat memperoleh niat atas apa yang mereka korbankan untuk mendapatkan sesuai dengan apa yang mereka harapakan. Pelayanan merupakan proses pemenuhan kebutuhan aktivitas

yang secara langsung dilakukan untuk memenuhi kebutuhan masyarakat sehinggga tercipta kepuasan. Terlebih lagi apalagi pelayanan itu telah menerapkan sistem yang canggih dengan alat tekhnologi yang memadai.

Berikut ini ada beberapa sifat pelanggan yang harus diperhatikan dan difahami oleh seorang kasir.

\section{Pelanggan Dianggap Sebagai Raja}

Petugas kasir harus menganggapa pelanggan sebagai raja yang harus dipenuhi semua keinginan dan kebutuhannya. Pelayanan yang di berikan harus sebaik mungkin layaknya seorang pelayanan yang diberikan kepada raja., namun masih dalam batas etika dan moral. Artinya dengan tidak merendahkan derajat perusahaan dan kasir itu sediri. 


\section{Mau Dipenuhi Keinginan dan Kebutuhannya}

Konsumen atau calon pelanggan pada hakikatnya tidak suka dibantah atau didebat. Artinya, usaha setiap pelayanan dilakukan melalui diskusi yang rileks dan santai. Petugas kasir juga harus pandai mengemukakan pendapat sehingga para pelanggan tidak akan mudah tersinggung.

\section{Konsumen merupakan Sumber Pendapatan}

Sebuah perusahaan pasti selalu ingin dianggap menjadi yang terbaik dimata konsumennya, oleh sebab itu, perusahaan harus memberikan pelayanan yang tebaik bagi para konsumen. Pelayanan yang baik harus bisa dipeneuhi oleh perusahaan sehingga keinginan pelanggan dapat diberikan secara maksimal.

\section{Pelanggan Mau Diperhatikan}

Setiap pelanggan atau konsumen dan calon pelanggan yang datang ke perusahaan pada hakikatnya inginn memperoleh perhatian dari pihak penjual. Oleh karena itu, petugas kasir harusnya memberikan perhatian secara penuh sehingga konsumen benar-benar merasa diperhatikan. Dalam Islam mengajarkan kepada umatnya untuk selalu memberikan pelayanan yang baik kepada pelanggan atas usaha yang dijalankan. Dapat di artikan bahwa kualitas pelayanan adalah suatu penilaian konsumen tentang kesesuaian tingkat pelayanan yang diberikan dengan tingkat pelayanan yang diharapkannya.

Kualitas pelayanan dapat diukur dengan enam dimensi, yakni sebagai berikut:

\section{Compliance (Kepatuhan)}

Compliance atau kepatuhan berkenaan dengan kepatuhan pelaku bisnis terhadap aturan atau hukum yang telah ditetapkan oleh Allah SWT atau disebut dengan Syari'at. Syari'at islam adalah aturan atau pedoman yang Allah turunkan untuk dilaksanakan oleh ummat Manusia dalam kehidupannya agar tercipta sebuah keharmonisan dan kebahagiaan. Hal ini sesuai dengan firman Allah dalam Al-qur'an surah Al-Maidah Ayat 48:

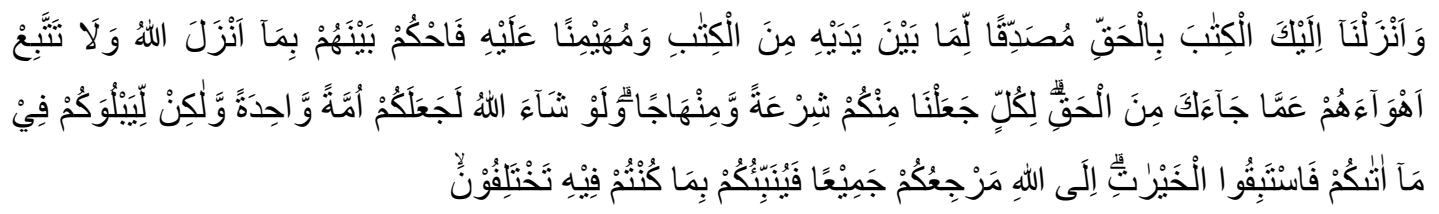

Dan Kami telah turunkan kepadamu Al Qur'an dengan membawa kebenaran, membenarkan apa yang sebelumnya, yaitu kitab-kitab (yang diturunkan 
sebelumnya) dan batu ujian terhadap kitab-kitab yang lain itu; maka putuskanlah perkara mereka menurut apa yang Allah turunkan dan janganlah kamu mengikuti hawa nafsu mereka dengan meninggalkan kebenaran yang telah datang kepadamu. Untuk tiap-tiap umat di antara kamu, Kami berikan aturan dan jalan yang terang. Sekiranya Allah menghendaki, niscaya kamu dijadikan-Nya satu umat (saja), tetapi Allah hendak menguji kamu terhadap pemberian-Nya kepadamu, maka berlombalombalah berbuat kebajikan. Hanya kepada Allah-lah kembali kamu semuanya, lalu diberitahukan-Nya kepadamu apa yang telah kamu perselisihkan itu”.

\section{Responsiveness (Daya Tanggap)}

Dimensi Responsiveness atau daya tanggap ini berkenaan dengan kesediaan pegawai dalam memberikan pelayanan yang cepat dan tepat kepada para konsumen atau pelanggan. Para pegawai harus profesional dalam melakukan pekerjaan, dikatakan profesional apabila bisa bekerja sesuai dengan keahlian dan kemampuannya sesuai dengan bidang pekerjaannya.

Sebuah kepercayaan yang diberikan kepada para pelanggan merupakan suatu amanah. Apabila amanh tersebut disia-siakan maka akan menimbulkan dampak pada kegaglan suatu perusahaan. Oleh karena itu, beriakan pelayanan secara profesional agar mendapat kepercayaan dari para konsumen melalui pegawai yang bekerja sesuai dengan bidangnya dengan tepat dan cepat.

\section{Reability (Keandalan)}

Reability Keandalan berkenaan dengan kemampuan untuk memberikan jasa yang dijanjikan secara akurat. Keakuratan dan ketepatan tersebut menumbuhkan rasa kepercayaan pelanggan terhadap perusahaan barang dan jasa. Dalam al- Qur'an di jelaskan tentang kewajiban untuk selalu menepati janji yakni pada surah An-Nahl ayat 91:

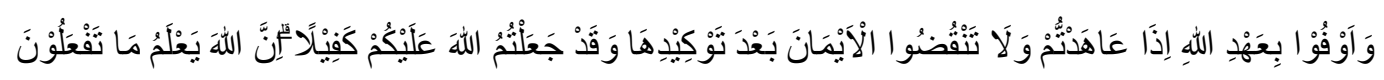

Dan tepatilah perjanjian dengan Allah apabila kaти berjanji dan janganlah kaти membatalkan sumpah-sumpah (ти) itu, sesudah meneguhkannya, sedang kamu telah menjadikan Allah sebagai saksimu (terhadap sumpah-sumpah itu). Sesungguhnya Allah mengetahui apa yang kamu perbuat. 


\section{Empathy (Empati)}

Dimensi Empathy (Empati) ini berkaitan dengan kemauan seorang pegawai untuk selalu peduli dan memberikan perhatian secara individu kepada pelanggan. Kemauan ini di tunjukkan melalui komunikasi, hubungan, perhatian, serta dapat memahami kebutuhan keluhan dari pelanggan. Dengan sikap empati tersebut dapat membuat pelanggan merasa kebutuhannya sudah terpenuhi dan puas karena telah dilayani dengan baik. Hal ini dapat direalisasikan melalui pemberian layanan informasi serta keluhan pelanggan, membantu para konsumen ketika mengalami kesulitan, serta melayani para pelanggan atau konsumen dengan penuh senang hati.

\section{Assurance (Kepastian)}

Dimensi Assurance atau Kepastian berkenaan dengan pengetahuan dan wawasan, kesantunan, kesopanan, kepercayaan diri dalam memberikan pelayanan, dan perspektif terhadap para pelanggan. Adanya sifat tersebut akan menjadi faktor meningkatnya persepsi positif dan nilai bagi para pelanggan terhadap perusahaan. Dengan sikap Assurance yang pasti akan meningkatkan rasa kepercayaan, rasa aman, serta bebas dari resiko dan bahaya sehingga membuat konsumen merasa puas. Dalam melayani pelanggan juga hendaknya bersikap lemah lembut yang sudah di ajarkan oleh nabi ketika berbisnis. Sebagaimana firman Allah dalam Surah Ali 'imran ayat 159:

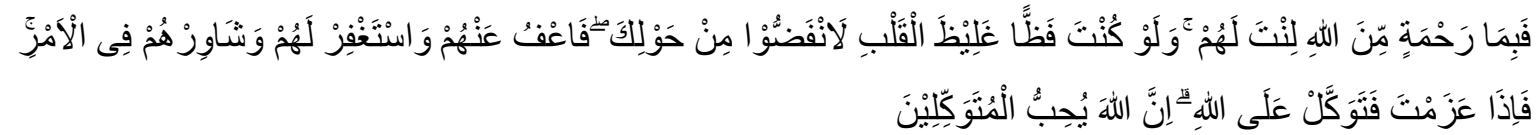

Maka disebabkan rahmat dari Allah-lah kamu berlaku lemah-lembut terhadap mereka. Sekiranya kamu bersikap keras lagi berhati kasar, tentulah mereka menjauhkan diri dari sekelilingmu. Karena itu maafkanlah mereka, mohonkanlah ampun bagi mereka, dan bermusyawarahlah dengan mereka dalam urusan itu. Kemudian apabila kamu telah membulatkan tekad, maka bertawakallah kepada Allah. Sesungguhnya Allah menyukai orang-orang yang bertawakal kepada-Nya”.

\section{Tangibles ( Berwujud)}

Tangibles atau bukti fisik berkenaan dengan fasilitas fisik seperti gedung dan ruangan yang nyaman, sarana prasarana lainnya. Dalam konsep Islam, pelayanan yang 
berkenaan dengan fasilitas fisik lebih utama mengutamakan kenyamanan pelanggan, bukan menunjukkan dengan sisi kemewahan.

\section{METODE PENELITIAN}

Penelitian yang akan digunakan peneliti adalah jenis penelitian kualitatif, Penelitian kualitatif adalah salah satu metode penelitian yang bertujuan untuk mendapatkan pemahaman tentang kenyataan melalui proses berfikir indukatif. Melauli penelitian kualitatif ini peneliti dapat mengenali subyek, merasakan apa yang mereka alami dalam kehidupan sehari-hari.

Dalam penelitian ini, peneliti dapat dikatakan sebagai pengumpul data sebagai instrument aktif dalam upaya mengumpulkan data-data di lapangan. Sedangkan instrumen pengumpulan yang lain selain manusia adalah berbagai bentuk alat-alat bantu dan berupa dokumen-dokumen lainnya yang dapat digunakan untuk menunjang keabsahan hasil penelitian, namun juga berfungsi sebagai instrumen pendukung. Oleh karena itu, kehadiran peneliti secara langsung dilapangan sebagai tolak ukur keberhasilan untuk memahami kasus yang diteliti, sehingga keterlibatan peneliti secara langsung dan aktif dengan informan atau sumber data lainnya disini mutlak diperlukan. Peneliti sangat setuju dengan pendapat LJ. Moelong yang menyatakan bahwa peneliti adalah "the researcher in the instrument", instrumen kunci dalam penelitian kualitatif (Sugiyono, 2012). Seorang peneliti yang sedang melakukan observasi ataupun interview harus hadir pada saat penelitian di lapangan, agar waktu dan tempat penelitian tidak bentrok dengan acara lain. Seorang peneliti harus mempunyai jadwal penelitian yang dapat disesuaikan dengan objek yang leluasa. Strategi peneliti harus dikonsep oleh peneliti agar pada saat melakukan observasi tidak ada data

yang tertinggal, serta agar menghemat waktu penelitian dilapangan. Penelitian ini bertempat di Toko Alfa Barokah yang lebih jelasnya berlokasi di Pulau Sapudi Desa Gayam, Kecamatan Gayam, Kabupaten Sumenep, Provinsi Jawa Timur.

Sumber data yang digunakan dalam penelitian ini adalah sumber data primer dan dan sumber data sekunder. Data primer peneliti peroleh langsung dari lokasi penelitian, sedangkan data sekunder adalah data-data yang peneliti dapatkan melalui sumber-sumber eksternal seperti buku, majalah dan lainnya. Sedangkan teknik pengumpulan data menggunakan observasi, wawancara dan dokumentasi. 


\section{HASIL DAN PEMBAHASAN}

Dalam menciptakan kepuasan Konsumen salah satunya adalah memberikan pelayanan yang prima terhadap konsumen. Berikut ini merupakan beberapa bentuk pelayanan yang di berikan oleh toko Alfa barokah kepada Konsuen yang sesuai dengan syari'at Islam:

\section{Perlakuan yang baik secara Islami}

Perlakuan yang baik dan sesuai dengan Syari'at terhadap para konsumen sangat berpengaruh terhadap minat konsumen dalam berbelanja. Seperti yang diterpkan oleh toko Alfa Barokah. Para karyawan toko Alfa Barokah menerapkan sikap senyum, sapa dan salam kepada para calon pelanggan. Dengan sikap inilah banyak konsumen yang loyal berbelanja ke tok Alfa Barokah karena salah satu bentuk pelayanan yang di berikan adalah memperlakukan calon pembeli dengan baik. Salah satu fakta yang di temukan adalah karyawan yang bertugas menjadi satpam di depan toko Alfa Barokah menyambut konsumen dengan lembut, senyum ramah dan menyapa konsumen seolah-olah sudah akrab dengan disertai raut muka yang tidak cemberut. Dengan sikap inilah pelanggan merasa di hormati. Kasmir memaparkan dalam bukunya yang berjudul "Kewirausahaan" bahwa Ketika melayani pelanggan, petugas kasir harus memiliki bersikap akrab dengan calon pelanggan, seolah-olah sudah kenal lama. Dalam melayani pelanggan juga harus murah senyum dengan raut muka yang menarik hati, serta tidak dibuat-buat.

Maka Dari itu, seorang karyawan haruslah bersikap baik dan murah senyum terhadap konsumen. Karena pada hakikatnya pembeli itu bukan hanya ingin di penuhi dan dilayani dengan baik, namun juga perlu di hargai dan di perlakukan dengan baik yang sesuai dengan apa yang telah di ajarkan dalam islam mengenai etika dalam berbisnis.

\section{Berpenampilan dan berpakaian rapi}

Penampilan juga harus di perhatikan, walaupun terlihat sepele namun itu juga termasuk penentu dari daya tarik konsumen dalam berbelanja. Berdasarkan fakta yang ditemukan di tempat bahwa di toko Alfa Barokah memiliki karyawan yang berpenampilan rapi. Karena bagi pihak toko Alfa Barokah penampilan itu perlu di perhatikan dalam melayani pelanggan. Untuk menarik perhatian pelanggan, para karyawan di toko Alfa Barokah selalu tetap menjaga penampilan semisal menggunakan seragam yang telah di 
berikan oleh pemilik toko dan di pakai sesuai dengan waktu yang telah di tentukan. Hal ini sesuai dengan pendapat kasmir dalam bukunya "Kewirausahaan" menyatakan bahwa Seorang kasir harus berpakain rapi, karena pakaian dan penampilan merupakan salah satu paket yang tidak dapat dipisahkan. Artinya petugas kasir harus menggunakan baju dan celana yang sepadan dengan kombinasi yang menarik, nicis, tidak kumal, dan baju lengan panjang yang tidak di gulung maupun dilipat sehingga pakaian yang digunakan benar-benar memikat perhatian pelanggan. Jika ada lebih baik menggunakan seragam sesuai dengan waktu yang ditetapkan. Cara berhias dan ekspresi wajah juga harus diperhatikan.

Oleh karena itu, penampilan itu harus tetap di perhatikan, karena terlihat kurang baik ketika melayani pelanggan dengan penampilan yang acak-acakan dan tak sesuai dengan syari'at Islam. Berpenampilan yang rapi juga sebenarnya dapat menarik perhatian terhadap pelanggan. Dengan demikian pelanggantidak akan merasa risih melihat penampilan karyawan dalam melayani pelanggan.

\section{Memiliki Karyawan yang Baik dan Sopan}

Bersikap baik dalam melayani pelanggan itu penting. Berdasarkan fakta yang di temukan oleh peneliti bahwa para karyawan toko Alfa Barokah memilik karyawan yang baik dan sopan dalam melayani pelanggan. Salah satunya adalah seperti kasir. Seorang kasir di toko Alfa Barokah bersikap baik dalam melayani pelanggan serta dengan tenang dan sabar dalam menghadapi pelanggan yang kadang menyampaikan keluhannya. Untuk meningkatkan kualitas pelayanan toko Alfa Barokah juga mengadakan pelatihan di setiap bulannya dengan mendatangkan pelatih yang sudah handal untuk memberikan pelatihan terhadap karyawan dalam meningkatkan kualitas pelayanan yang seharusnya diberikan kepada para konsumen. Berdasarkan teori yang di paparkan oleh Kasmir dalam bukunya "Kewirausahaan", Adapun karyawan yang melayani seorang konsumen itu adalah kasir. Kasir merupakan salah satu faktor penentu utama tercapainya kesuksesan suatu perusahaan selama melayani konsumen, salah satunya kenyamanan pelanggan itu tergantung dari kasir yang melayaninya, petugas kasir itu harus berpenampilan rapi, bersikap sopan, ramah, dan juga menaraik. Selain itu, petugas kasir harus cepat dan tanggap, menyenangkan, pandai bicara serta pintar. Petugas kasir harus mampu memikat dan mengambil hati konsumen sehingga konsumen semakin tertarik. Cara kerjanya pun harus cepat dan cekatan. Sebelum 
diterjunkan, seorang kasir harus mengikuti pendidikan dan pelatihan khusus dari perusahaan tersebut.

jadi, bersikap baik merupakan suatu keharusan yang harus di miliki oleh setiap karyawan, salah satunya adalah dengan tetap memperhatikan etika dalam berbisnis, salah satunya adalah dengan memperlakukan para konsumen dengan sebaik mungkin. Dengan demikian maka akan tercipta kepuasan konsumen dan loyalitas pelanggan terhadap toko Alfa Barokah, adanya perlakuan yang baik dari karyawan terhadap konsumen dalam melayani pelanggan maka para konsumen akan merasa terlayani dengan baik.

\section{Tersedianya Sarana dan Parasarana Bagi Para Konsumen}

Tersedianya sarana dan prasarana bagi konsumen itu penting. Fakta yang di temukan di toko Alfa Barokah sudah menyediakan beberapa sarana dan prasarana, salah satunya adalah menyiapkan ruangan yang luas dan bersih, serta menyiapkan tempat parkir gratis untuk para pelanggan yang hendak berbelanja, adanya tempat parkir ini merupakan salah satu bentuk pelayanan yang di berikan oleh toko Alfa Barokah yang tujuannya adalah agar kendaraan konsumen terjamin keamanannya sehingga dengan demikian konsumen akan tenang dalam berbelanja.

Jadi dengan Tersediaya sarana dan prasarana ini salah satunya adalah menyiapkan ruangan yang luas dan keadaan ruangan yang bersih dan nyaman merupakan salah satu upaya yang harus di lakukan dalam mencipkan kepuasan konsumen. Tersedianya tempat parkir juga merupakan hal yang perlu diperhatikan, kerena tempat parkir merupakan salah satu bentuk pelayanan terhadap konsumen untuk memberikan keamanan dan kenyamanan kepada setiap konsumen yang membawa kendaraan. Dengan seperti itu kosumen tertarik untuk berbelanja di toko tersebut dan dan tidak khawatir lagi dengan kendaraan yang mereka bawa. Dalam dunia bisnis, hal yang harus diperhatikan adalah pelayanan terhadap konsumen, dan parkir merupakan salah satu yang menjadi kelengkapan pelayanan.

\section{Pelanggan Dianggap Seperti Raja.}

Berdasarkan fakta yang di temukan bahwa karyawan toko Alfa Barokah selalu memberikan pelayanan yang prima kepada konsumennya. Salah satunya adalah ssalah satu kasir memperlakukan para konsumen dengan baik. Karena menurut mereka pelanggan itu 
diibarakan seperti raja yang layak di suguhkan pelayanan dengan sebaik-baiknya. Dengan hal ini maka konsumen akan merasa terlayani dengan maksimal.

Petugas kasir harus menganggap pelanggan sebagai raja yang harus dipenuhi semua keinginan dan kebutuhannya. Pelayanan yang di berikan harus sebaik mungkin layaknya seorang pelayanan yang diberikan kepada raja, namun masih dalam batas etika dan moral. Artinya dengan tidak merendahkan derajat perusahaan dan kasir itu sediri. Maka dari itu, dalam melayani pelanggan harus tetap memperhatikan etika. Memberikan pelayanan terbaik itu penting apalagi memluiakan pelanggan. Pelanggan itu bukan hanya ingin dipenuhi kebutuhannya tapi juga butuh di hargai dan di perhatikan. Dengan demikian perlu untuk tetap memperhatikan faktor apa saja yang dapat memuaskan pelanggan.

Faktor Penghambat dan Pendukung dalam Meningkatkan Kepuasan Konsumen di Toko Alfa Barokah

\section{Faktor Penghambat}

Dalam setiap usaha pasti ada beberapa faktor baik faktor penghambat maupun pendukungnya. Di toko Alfa Barokah ada salah satu faktor yang emnjadi penghambat dalam dunia pemasaran, yakni dalam bidang kepuasan konsumen. Banyak para konsumen merasa kecewa karena barang yang mereka butuhkan tidak ada atau stok kosong akibat dari faktor cuaca yang kadang tidak stabil. Akibatnya banyak para pelanggan yang keinginannya tak terpenuhi.

Rusdiana memaparkan dalam bukunya" Kewirausahaan Teori dan Praktik" bahwa Kepuasan pelanggan adalah penilaian pelanggan terhadap produk atau pelayanan yang memberikan tingkat kenikmatan seperti yang diharapkan. Harapan itu berupa kemampuan perusahaan dalam menyediakan produk pelayanan, harga maupun aspek lain yang sesuai dengan apa yang diinginkan pelanggan atau konsumen.

Maka dari itu, sebaiknya toko Alfa Barokah harus selalu memperhatikan barangbarang yang akan habis agar segera memesan barang ketika cuaca masih bersahabat dengan sebanyak-banyaknya dengan tetap memperhatikan tanggal kadaluarsanya dan tentunya juga memperhatikan kualitas barangnya. Dengan menyediakan barang yang dibutuhkan konsumen maka kepuasan konsumen juga akan tercipta. 


\section{Faktor Pendukung}

Berikut merupakan beberapa faktor pendukung dalam melayani pelanggan di toko Alfa Barokah, diantaranya:

\section{Compliance Kepatuhan dan Kedisiplinan Karyawan}

Berdasarkan fakta yang di temukan di toko Alfa Barokah adalah para karyawan disana patuh terhadap peraturan yang telah di buat oleh pimpinan mereka. Seperti karyawan yang disiplin waktu, artinya para karyawan di toko Alfa Barokah datang ke lokasi tepat waktu. Dengan disiplin waktu maka juga akan berpengaruh terhadap lancarnya suatu usaha dan juga akan berpengaruh dalam memberikan pelayanan kepada konsumen. Compliance atau kepatuhan berkenaan dengan kepatuhan pelaku bisnis terhadap aturan atau hukum yang telah ditetapkan oleh Allah SWT atau disebut dengan Syari'at. Syari'at islam adalah aturan atau pedoman yang Allah turunkan untuk dilaksanakan oleh ummat Manusia dalam kehidupannya agar tercipta sebuah keharmonisan dan kebahagiaan. Jadi, mematuhi peraturan yang sudah di tetapkan oleh atasan itu penting, karena disiplin waktu juga penting dalam bekerja. Dengan demikian sebagai karyawan yang baik hendaknya tetap memperhatikan waktu termasuk disiplin datang ke toko. Jika lambat maka juga akan berpengaruh terhadap kepuasan konsumen dalam melayani pelanggan.

\section{Reability (Keandalan) Karyawan}

Berdasarkan fakta yang di temukan oleh peneliti bahwa toko Alfa Barokah memiliki karyawan yang handal. Seperti para karyawan disana bekerja sesuai dengan kemampuannya masing-masing.salah satunya adalah pihak toko Alfa Barokah tidak sembarangan memilih seorang kasir, seorang kasir memang harus benar-benar handal. Karena kasir itu merupakan salah satu faktor penentu utama tercapainya suatu perusahaan termasuk dalam bidang pelayanan. Reability Keandalan berkenaan dengan kemampuan untuk memberikan jasa yang dijanjikan secara akurat. Keakuratan dan ketepatan tersebut menumbuhkan rasa kepercayaan pelanggan terhadap perusahaan barang dan jasa. Jadi, dengan adanya keandalan dari karyawan akan tercipta kepercayaan konsumen terhadap kemampuan mereka dalam melayani para konsumen dengan baik. 


\section{Memiliki Rasa Empati (Peduli)}

Rasa Empati terhadap sesama itu sangatlah penting. Karena pada hakikatnya setiap manusia memiliki rasa peduli tehadap sesama. Berdasarkan fakta yang ditemukan di toko Alfa Barokah bahwa karyawan disana memiliki rasa empati yang tinggi terhadap pelanggannya. Salah satunya adalah ketika ada para konsumen yang sedang kebingungan dalam mencari barang yang dibutuhkan maka dengan sabar dan tanggap mencarikan barang dan mengantarkan konsumen tersebut ke rak barang tersebut atau memesankan barang yang di carinya jika stok masih kosong. Sebagaiman dalam kajian teori bahwa Dimensi Empathy (Empati) ini berkaitan dengan kemauan seorang pegawai untuk selalu peduli dan memberikan perhatian secara individu kepada pelanggan. Kemauan ini di tunjukkan melalui komunikasi, hubungan, perhatian, serta dapat memahami kebutuhan keluhan dari pelanggan. Dengan sikap empati tersebut dapat membuat pelanggan merasa kebutuhannya sudah terpenuhi dan puas karena telah dilayani dengan baik. Hal ini dapat direalisasikan melalui pemberian layanan informasi serta keluhan pelanggan, membantu para konsumen ketika mengalami kesulitan, serta melayani para pelanggan atau konsumen dengan penuh senang hati. Oleh karena itu, memiliki rasa empati terhadap pelanggan itu juga penting untuk di terapkan oleh para karyawan. Karena, jika seandainya dalam melayani pelanggan menunjukkan sikap acuh tak acuh terhadap pelanggan, kemungkinan besar hal yang akan terjadi respon atau tanggapan dari pelanggan akan beranggapan bahwa pelayanan yang diberikan tidak sesuai dengan apa yang menjadi harapan konsumen tersebut. Hal ini perlu di perhatikan, dengan adanya rasa empati dari para karyawan terhadap konsumen akan tercipta kepuasan konsumen dan loyalitas pelanggan terhadap barang maupun pelayanan ssudah terpenuhi dengan baik dan maksimal

\section{KESIMPULAN}

Manajemen pelayanan Islami dalam meningkatkan kepuasan konsumen di toko Alfa Barokah memiliki beberapa hal yang sesuai dengan yang di ajarkan oleh islam dalam berbisnis, antara lain: Pertama, Penerapan 3S (Senyum, Sapa dan Salam) terhadap pelanggan, kedua, Menjaga penampilan dan berpakaian rapi dalam melayani pelanggan, Ketiga, memiliki karyawan yang baik dan sopan, keempat, menyediakan sarana dan Prasarana untuk para pelanggan. 
Faktor penghambat di toko Alfa Barokah adalah ketika mengurangnya stok barang akibat cuaca buruk yang tak bisa memesan barang ke distributor, karena letak toko Alfa Barokah itu menyeberangi lautan ketika pengiriman barang dari distributor menunggu cuaca baik. Hal inilah yang berpengaruh terhadap kepuasan konsumen. Faktor pendukung di toko Alfa barokah diantaranya adalah: Kepatuhan (Compliance) yang dimiliki oleh karyawan toko Alfa Barokah seperti karyawan yang memeatuhi peraturan untuk selalu disiplin datang tepat waktu. Keandalan (Reability) yang dimiliki karyawan toko Alfa Barokah adalah bekerja sesuai dengan kemampuan yang mereka miliki. Empati (Empathy) dalam melayani pelanggan, ketika ada konsumen yang kebingungan mencari barang, maka karyawan toko Alfa Barokah dengan sabar membantu pelanggan mencari barang yang mereka butuhkan

\section{DAFTAR PUSTAKA}

A.A.Anwar Mangkunegara. (2012). Prilaku Konsumen. Bandung : PT.Refika Aditama.

Dewi Maharani purbasari, Dewi Laili Purnama Sari. (2018). Pengaruh Kualaitas Pelaayanan dan Kepuasan Pelanggan Terhadap Pembelian Uang. Jurnal Inspirasi Bisni dan Manajemen .

Philip Kotler. (2008). Prinsip-prinsip Pemasaran. Jakarta: Erlangga.

Ratminto, Atik septiwinarsih. (2007). Manajemen pelayanan. Yogyakarta: Pustaka Pelajar.

Rivai Veithzal, dkk. (2017). Islamic Business Management Praktik Manajemen Bisnins Yang Sesuai Syari'at Islam. yogyakarta: BPFE.

Rivai Veithzal, dkk. (2017). Islamic Bussines Managemen. Yogyakarta : BPFE.

Rusdiana. (2014 ). Kewirausahaan Teori dan Praktik. Bandung: Pustaka Setia.

Sugiyono. (2012). Metode Penelitian Kuantitatif, Kualitatif, dan R\&D. Bandung : Alfa Beta.

WJS Poerwa Darminta. (1976). Kamus Umum Bahasa Indonesia. Jakarta: Bumi Pustaka. 